\title{
Short Communication: Intra-Individual Microwear Variation: Deciduous versus Permanent Dentition
}

\author{
Tammy R. Gamza \\ Department of Anthropology, Southern Illinois University-Carbondale, IL
}

ABSTRACT This study compares microwear patterns on deciduous and permanent dentition within individuals. Number of features, total number of pits, mean pit breadth and mean scratch breadth are compared in 11 individuals aged 6-12 years. For each individual, the second deciduous molar and first permanent molar are used. Paired sample t-tests show no significant difference between deciduous and permanent enamel for any of the microwear features

Analysis of dental microwear has aided in the interpretation of human diet for a number of populations over the last few decades (e.g., Fine and Craig, 1981; Harmon and Rose, 1988; Hojo, 1989; Laleuze et al., 1993; Molleson et al., 1991; 1993; Danielson and Reinhard, 1998; Schmidt, 2001; Teaford, 2002; Organ, 2005). The majority of these studies rely on microwear of permanent dentition; only a few have used the deciduous dentition (Bullington, 1991; Greene, 2007). Despite investigations into Gordon's claims $(1980,1982)$ that microwear varies with age (Teaford and Oyen, 1986, 1988, 1989; Bullington, 1991), no study has compared the microwear of deciduous and permanent teeth. This aim of the present study is to determine if microwear patterns differ between deciduous and permanent molars of the same individual. Given the same diet, can deciduous and permanent enamel be expected to show similar microwear patterns?

We know that the physical and chemical properties of deciduous and permanent enamel differ (LeGeros et al., 1983; Kornblit et al., 2009). Enamel of deciduous teeth is somewhat softer than that of the permanent dentition. This is due to the spatial organization of the enamel prisms, which is more loosely organized in deciduous enamel. Often, superficial deciduous enamel is aprismatic (Kornblit et al., 2009). It also tends to be less mineralized and more porous (LeGeros et al., 1983; Kornblit et al., 2009). Several studies have shown that deciduous enamel erodes at a faster rate than permanent enamel when exposed to acids (Amaechi et al., 1999; Hunter et al., 2000; Lippert et al., 2004). Lippert and colleagues (2004) show that deciduous enamel is significantly softer after being exposed to acid and therefore at higher risk of abrasion and attrition than permanent enamel. Given a faster rate of wear and higher predisposition of deciduous enamel to abrasion, a greater number of microwear features or larger microwear features might be expected. examined. This study suggests that differences in the physical and chemical structures of deciduous and permanent enamel are not sufficient to cause differences in microwear patterning. Any difference between juveniles and adults can be assumed to represent a true dietary difference rather than enamel structural differences. Dental Anthropology 23(2):66-68.

\section{MATERIALS AND METHODS}

A total of 11 individuals were chosen for the study; five from Hierakonpolis and six from Naqada. Both locations are Predynastic sites in Upper Egypt dating to 3,800-3,650 BC. The two sites have been shown to have similar diets (Greene, 2007). Individuals in this sample fell within the 6 to 12 year age range and had both a deciduous second molar and permanent first molar erupted and in occlusion. While most researchers use the mandibular left second molar (Gordon, 1982; Harom and Rose, 1988; Kay, 1987; Schmidt, 1998), deciduous molars would not be expected to remain in occlusion until the eruption of the second molar.

Casts of the teeth were prepared following Schmidt (1998). Casts were separated and given unique random numbers so the researcher did not know which teeth were a pair during study. Micrographs were taken of the Phase II wear facet (as defined by Kay, 1977). Images were obtained on an International Scientific Instruments (ISI40) SEM at 500X magnification in the secondary emissions mode (Teaford and Walker, 1984; Teaford, 1984, 1991, 1994; Teaford et al., 1996). Images were transferred directly from the SEM to computer via an Iridium Digital Imaging System. A semi-automated computer program, Microwear 4.0 (Ungar, 2000), was used to analyze digital images of the tooth surface. Microwear characteristics examined include total number of features (pits and scratches), total number of pits, mean breadth of pits, and mean breadth of scratches (Table 1). Comparisons were made between the deciduous and permanent molar using paired-sample t-tests.

Correspondence to: Tammy R. Gamza, Department of Anthropology, Mail code 4502, Southern Illinois University Carbondale, Carbondale, Illinois 62901

E-mail: gamza@siu.edu 
TABLE 1. Mean values and standard deviations for deciduous and permanent molars

\begin{tabular}{lrrrr}
\hline & \multicolumn{2}{c}{ Deciduous molars } & \multicolumn{2}{c}{ Permanent molars } \\
& mean & sd & mean & sd \\
\hline Total number of features & 35.18 & 24.28 & 47.73 & 34.42 \\
Total number of pits & 17.45 & 15.08 & 22.55 & 22.56 \\
Mean pit breadth & 8.63 & 5.66 & 9.46 & 4.86 \\
Mean striation breadth & 3.65 & 2.53 & 2.86 & 1.06 \\
\hline
\end{tabular}

\section{RESULTS AND DISCUSSION}

The differences between the deciduous and permanent molar were generally small for all individuals. Figure 1 shows the deciduous and permanent dentitions with the greatest overall differences. The average feature tally differs by 13 features, with the majority differing by less than 10 features. The average pit tally differs by only five pits, with the majority differing by less than five. Mean pit breadth differs by $0.1 \mu \mathrm{m}$ to $4.44 \mu \mathrm{m}$, with the majority differing by less than $2 \mu \mathrm{m}$. One individual was not included in the test for mean pit breadth because this individual did not exhibit any pits on the deciduous molar. Mean striation breadth differs by $0.29 \mu \mathrm{m}$ to $8.58 \mu \mathrm{m}$, with the majority differing by less than $1 \mu \mathrm{m}$. Paired-samples t-tests showed no significant difference between the deciduous and permanent molars for any of the characteristics examined (Table 2).

The results of this study suggest that, despite some small differences, the deciduous and permanent enamel generally react the same way in regard to microwear features. Although the deciduous and permanent teeth were not identical in each individual, the differences were no greater than intertooth differences between first and second permanent molars of the same individual (Mahoney, 2006). Therefore, subadults with deciduous dentition can reasonably be included in population studies of microwear. Also, any difference in microwear patterns between juveniles and adults within a population should represent actual dietary differences rather than differences in enamel structure.

\section{ACKNOWLEDGMENTS}

I would like to thank Dr. Renee Friedman, Director of the Hierakonpolis Expedition for permission to study the Hierakonpolis sample and for her hospitality during my stay at Hierakonpolis. I thank Dr. Maggie Bellatti and

TABLE 2. Paired-sample t-tests between deciduous and permanent molars

\begin{tabular}{lrrr}
\hline \multicolumn{1}{c}{ Variable } & \multicolumn{1}{c}{$\mathrm{d}$} & $\mathrm{df}$ & $\mathrm{P}$ \\
\hline Total number of features & -1.315 & \multicolumn{1}{c}{10} & 0.218 \\
Total number of pits & -0.741 & 10 & 0.476 \\
Mean pit breadth & -0.952 & 9 & 0.366 \\
Mean striation breadth & 0.886 & 10 & 0.396 \\
\hline
\end{tabular}

Dr. Robert Foley of the Leverhulme Center for Human Evolutionary Studies at the University of Cambridge for permission to study the Naqada sample. Travel was made possible by a NSF grant (\#BCS-0119754) awarded to Jerome Rose of the University of Arkansas. Use of the scanning electron microscope was possible thanks to the Deans' Special Projects Fund, College of Natural Science and Mathematics, University of Alaska Fairbanks.

\section{LITERATURE CITED}

Amaechi BT, Higham SM, Edgar WM. 1999. Factors influencing the development of dental erosion in vitro: enamel type, temperature and exposure time. J Oral Rehabil 26: 624-630.

Bullington J. 1991. Deciduous dental microwear of prehistoric juveniles from the lower Illinois River Valley. Am J Phys Anthropol 84:59-73.

Danielson DR, Reinhard KJ.1998. Human dental microwear caused by calcium oxalate phytoliths in prehistoric diet of the lower Pecos region, Texas. Am J Phys Anthropol 107:297-304

Fine D, Craig GT. 1981. Buccal surface wear of human premolar and molar teeth: a potential indicator of dietary and social differentiation. J Hum Evol 10:335344.

Gordon KD. 1980. Dental attrition in the chimpanzee (Pan troglodytes uersus): a scanning electron microscope study. Ph.D. dissertation, Yale University, New Haven, CT.

Gordon KD. 1982. A study of microwear on chimpanzee molars: Implications for dental microwear analysis.

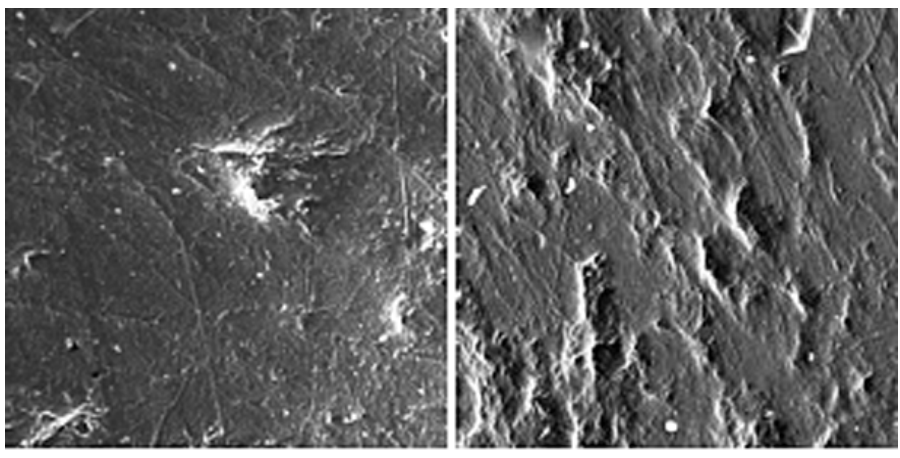

Fig. 1. Microwear images showing the greatest difference between deciduous and permanent dentition represented in this sample: (left) deciduous dentition; (right) permanent dentition. 
Am J Phys Anthropol 59:195-215.

Greene TR. 2007. Diet and dental health in Predynastic Egypt. Berlin: VDM Verlag Dr. Muller.

Harmon AM, Rose JC. 1988. The role of dental microwear analysis in the reconstruction of prehistoric diet. In: Kennedy BV, Le Moine GM, editors. Diet and subsistence: current archaeological perspectives. Calgary, Alberta: Archaeological Association of the University of Calgary. p 267-272.

Hojo T. 1989. Dietary differences and microwear on the teeth of Late Stone Age and early modern people from western Japan. Scan Microsc 3:623-628.

Hunter ML, West NX, Hughes JA, Newcombe RG, Addy M. 2000. Erosion of deciduous and permanent dental hard tissue in the oral environment. J Dent 28:257-263.

Kay RF. 1977. The evolution of molar occlusion in the Cercopithecidae and early Catarrhines. Am J Phys Anthropol 46:327-352.

Kay RF. 1987. Analysis of primate dental microwear using image processing techniques. Scan Microsc 1:657-662.

Kornblit R, Bossu M, Mari D, Rocca JP, Polimeni A. 2009. Enamel and dentine of deciduous teeth Er:YAG laser prepared. A SEM study. Eur J Paed dent 10:75-82.

Lalueza Fox C, Pérez-Pérez A. 1993. The diet of the Neanderthal child Gibralter 2 (Devils' Tower) through the study of the vestibular striation pattern. J Hum Evol 24:29-41.

LeGeros RZ, Piliero JA, Pentel L. 1983. Comparative properties of deciduous and permanent (young and old) human enamel. Gerodontology 2:1-8.

Lippert F, Parker DM, Jandt KD. 2004. Susceptibility of deciduous and permanent enamel to dietary acidinduced erosion studied with atomic force microscopy nanoindentation. Eur J Oral Sci 112:61-66

Mahoney P. 2006. Brief communication: Intertooth and intrafacet dental microwear variation in an archaeological sample of modern humans from the Jordan Valley. Am J Phys Anthropol 129:39-44.

Molleson T, Jones K. 1991. Dental evidence for dietary change at Abu Hureyra. J Archaeol Sci 18:525-539.

Molleson T, Jones K, Jones S. 1993. Dietary change and the effects of food preparation on microwear patterns in the Late Neolithic of Abu Hureyra, northern Syria. J Hum Evol 24:455-468.
Organ JM, Teaford MF, Larsen CS. 2005. Dietary inferences from dental occlusal microwear at Mission San Luis de Apalachee. Am J Phys Anthropol 128:801-811.

Schmidt CW. 1998. Dietary reconstruction in prehistoric humans from Indiana: an analysis of dental macrowear, dental pathology, and dental microwear. Ph.D. dissertation, Purdue University.

Schmidt CW. 2001. Dental microwear evidence for a dietary shift between two nonmaize-reliant prehistoric human populations from Indiana. Am J Phys Anthropol 114:139-145.

Teaford MF. 1984. Molar microwear and diet in the genus Cebus. Am J Phys Anthropol 66:363-370.

Teaford MF. 1991. Dental microwear: what can it tell us about diet and dental function? In: Kelley MA, Larsen CS, editors. Advances in dental anthropology. NewYork: Wiley-Liss. p 341-356.

Teaford MF. 1994. Dental microwear and dental function. Evol Anthropol 3:17-30.

Teaford MF. 2002. Dental enamel microwear analysis. In: Hutchinson DL, editor. Foraging, farming and coastal biocultural adaptation in late prehistoric North Carolina. Gainesville, Florida: University Press of Florida. p 169-177.

Teaford MF, Oyen OJ. 1986. Dental microwear in vervets raised on different diets. Am J Phys Anthropol 69:270.

Teaford MF, Oyen OJ. 1988. In vivo and in vitro turnover in dental microwear. Am J Phys Anthropol 75:279.

Teaford MF, Oyen OJ. 1989. In vivo and in vitro turnover in dental microwear. Am J Phys Anthropol 80:447-460.

Teaford MF, Walker, A. 1984. Quantitative differences in dental microwear between primate species with different diets and a comment on the presumed diet of Sivapithecus. Am J Phys Anthropol 88:347-364.

Teaford MF, Maas MC, Simons E. 1996. Dental microwear and microstructure in early Oligocene primates form the Fayum, Egypt: implications for diet. Am J Phys Anthropol 101:527-543.

Ungar PS. 2000. Microware 4.0. 